\title{
Azyumardi Azra: Intellectual Indonesian Muslim Leader
}

\author{
Iswantir $^{1}$, Zulfani Sesmiarni ${ }^{2}$, Kaila Saparina ${ }^{3}$ \\ \{iswantir@iainbukittinggi.ac.id ${ }^{1}$, zulfanisesmiarni@gmail.com ${ }^{2}$, kailasapagina@gamil.com ${ }^{3}$ \} \\ Islamic Education Departement, Institut Agama Islam Negeri (IAIN) Bukittinggi, Indonesia+1,2,3
}

\begin{abstract}
The focus of this research is to study and analyze Azyumardi Azra as an Indonesian intellectual Muslim figure who has a national and international reputation. This research is a character research in the form of library research. The method of data analysis is qualitative. The results of this study are Azra fulfill the criteria as a global Indonesian Muslim intellectual figure, this can be seen from several things, first; the results of his work, both in written form and work in the development of Islamic religious colleges, second; awards he received from various countries and international institutions, third; activity in several international organizations, and fourth; is often invited as a guest speaker in various international event
\end{abstract}

Keyword. Azyumardi Azra, intellectual Muslim

\section{Introduction}

Azyumardi Azra (hereinafter referred to as Azra) is a thinker who never stands still. His great obsession to change Islamic thought in Indonesia has also been inscribed through his genius works, both in the form of written articles and essays published in various mass media as well as a number of books that have been published.[1] Azra is one of Indonesia's most productive Muslim figures in various international forums, and even won several international awards. Azra was born in Lubuk Alung, an area in the center of the sub-district in Padang Pariaman on the edge of the Bukittinggi-Padang highway in West Sumatra, on March 4,1955. [2] His name often adorns various media because of his sharp analysis. Welcoming the new year 2000 and the 3rd millennium, for example, his column writings appeared in several written media; Tempo, Forum Keadilan, Panji Masyarakat, Gatra, Kompas, dan Media Indonesia [1] Until now, Azra is still a productive writer, so his name still often adorns the mass media, both electronic and non electronic. Even today, Azra is still actively filling in the Republika Resonance column. No wonder then that he is often used as a resource of the journalists who want interesting and noteworthy news. This shows that Azra's thoughts are clear, factual, accurate and sharp. [1] Azra's recognition as a figure and scholar is not only at the national level, but also comes from the international world. 


\section{Azyumardi Azra: Indonesian Muslim Intellectual Leader In The World}

Azra is one of Indonesia's most productive Muslim intellectual figures. The recognition of Azra's productivity led him to receive awards from various groups, both national and international. Azra's recognition as an Indonesian Muslim intellectual figure who has an international reputation come from various institutions, both at home and abroad.

Azra is worth mentioning as an Indonesian Muslim intellectual figure whose expertise is comprehensive. It can be seen from an educational background, work and devotion which he elaborated. Azra has works from various perspectives, such as history, culture, politics, education, and religion. Azra's works, not only written in Indonesian, but also foreign languages, especially English. His work is used as a reference by various groups, both national and international. Azra's expertise in these various matters made him one of the Indonesian Muslim intellectual figures who were often invited to an international conference, and could be said to be an Indonesian Muslim intellectual figure who was often a resource or speaker at the international level.

Azra's talent and expertise development in the field of science began to grow when in 1986 he obtained a scholarship from Fulbright provided by the United States government to continue his master's degree at Columbia University, New York, United States and study history there. Within two years he successfully completed his MA program at the Department of Languages and Culture in the Middle East (1988). Thesis he wrote at that time titled The Research and Decline of The Minangkabau Surau: A Traditional Islamic Education in West Sumatra Institutional dur i ng the Dutch Colonial Government . [1]

Furthermore, through the Columbia University President Followship program , Azra continued her studies at the Department of History, at the same university, and studied history there. From this department, he obtained his second MA in 1989, and added his M. Phil in 1999 in history. Finally, from this history department, Azra obtained her Ph.D. two years later, precisely in 1992. And to complete this S3 program, Azra wrote a dissertation, which later became one of the great and original thoughts that she produced. The full title of the dissertation is: " The Transmission of Islamic Reformism to Indonesia: Networks of Middle Eastern and Malay Indonesian Ulama in the Seventeenth and Eighteen Centuries ". This dissertation is the result of more than two years of research in various cities and libraries, ranging from Banda Aceh, West Sumatra, Jakarta, Ujung Pandang, Yokyakarta, Cairo, Mecca, Medina, Leiden, New York City, to Ithaca (New York State). [1]

After steal two MA degrees, one M. Phil, and a Ph.D. .D, Azra still keen to follow post doctoral program at Oxford University for one year from 1995 to 1996). [1] When he was back in 1996 Azra slowly but sure began to reap the fruits of the seeds he was cultivating. He continued his activities as Editor in Chief in the Journal of Studia Islamika. Through this journal which is now a religious journal that is accredited with the value of A, Azra has poured her genuinist thoughts, so that her name is immediately known in the international scientific world, especially by observers of Islamic Southeast Asia. [1]

Azra soon became a favorite of several universities abroad to make him a visiting lecturer ( visiting professor ). In 1997, for example, he was a guest lecturer at the University of Philippines, Diliman, and Malaya University. Previously Azra had also been a visiting fellow at South Asian Asian Studies, Oxford Center for Islamic Studies, Oxford University, besides teaching at St. Anthony College. Since 1997 until now, Azra has also been a member of the Selection Committee of SEASREP ( Southeast Asian Regional Exchange Program ), which is organized by the Toyota Faoundation and The Japan Foundation . He is also an external 
examiner ( exsternal examine ) for theses and dissertations at Universiti Malaya, Leiden University, The Australian University, and the University of Melbourne. [1]

During his time at IAIN Syarif Hidayatullah Jakarta, in addition to being Editor in Chief of the Journal of Islamic Studies, Azra was also entrusted with responsibility as Deputy Director of the Center for Islamic and Community Studies (PPIM) Syarif Hidayatullah Jakarta until 1997. After that, Azra's academic and scientific career improved along with the increasing number of writings he delivered on various seminar forum opportunities, both at home and abroad. Seeing such great potential, Prof. Dr. M. Quraish Shihab, asked him to sit in the leadership ranks as Assistant Chancellor for Academic Affairs IAIN Syarif Hidayatullah Jakarta. This position was initially rejected, because he wanted to become an independent scholar, be an observer, or just a researcher. After putting forward various arguments for rejection, Azra finally accepted the position. [1]

Along with the changes in national leadership, where Prof. Dr. HM Quraish Shihab was appointed as Minister of Religion, Azra was also without many obstacles being appointed as the Chancellor of IAIN Syarif Hidayatullah Jakarta. The comment he gave when he was appointed as chancellor was: "I became the chancellor because of the disaster of reform". Despite being the number one super busy person at IAIN Syarif Hidayatullah Jakarta, he is a very productive scientist and is regarded by people as an intellectual celebrity. [1]

But such a prestigious position at IAIN Syarif Hidayatullah Jakarta does not change his attitude and simple lifestyle. He remained unpretentious and lived a lifestyle like other people in general. He is so committed to advancing and elevating the degree of Muslims through the educational institutions he leads accompanied by his firm and full of trust. His honesty and trustworthy attitude were truly tested. This can be seen from the actions and supervision he has carried out on various activities that he does primarily from the financial aspect. He did not hesitate to take strict action against subordinates who commit violations. [1]

Azra is an honorary professor at the University of Melbourne (2006-2009), member of the International Islamic University Trustees Board, Islamabad, Pakistan (2005-present), Academic Committee of The Institute for Muslim Society and Culture (IMSC), International Aga Khan University, London (2005 -2010). In the field of science and research, Azra is a member of the Indonesian Academy of Sciences (AIPI, 2005-present); member of the National Research Council (DRN, 2005-present). Also a member of the Southeast Asian Regional Exchange Program (SEARSREP), Tokyo (1999-2001); Asian Research Foundation-Asia Muslim Action Network (ARF-AMAN) , Bangkok (2004-present); The Habibie Center Scholarship (2005present); Ford Foundation International Fellowship Program (IFP-IIEF), (2006-present); Asian Scholarship Foundation (ASF), Bangkok (2006-present); Asian Public Intellectual (API), The Nippon Foundation, Takyo, (2007-present); Member of the AMINEF Senior Fellow Selection Committee Commite-Fulbright, (2008).[3]

In addition, Azra became a member of the Founding Council of Partnership for Governance Reform in Indonesia (2004-present); Advisory Board of the United Nations Democracy Fund ( UNDEF , New York), (2006-2008); International IDEA (Institute for Democracy and Electoral Assistance), Stockholm, (2007-present); Multi Faith Center, Griffith University, Brisbane (2005-present); Institute of Global Ethics and Religion, USA, (2004present); Libfor All , USA (2006-present); The Center for the Study of Contemporary Islam (CSCI) , University of Melbourne, (2205-2007); Tripartite for Inter-Faith Cooperation , New York, (2006-present); member of the World Economic Forum's Global Agenda Council on The West-Islamic Dialogue, Davos, (2008-present). [3]

In 2005 Azra received The Asian Foundation Award in celebrating 50 years of TAF for its important role in the modernization of Islamic education; in commemoration of the Republic of 
Indonesia's Independence Day, on August 15, 2005, was awarded the Bintang Mahaputra Utama RI for its contribution in the development of modern Islam; and in September 2010, he was awarded the CBE ( Commander of the Order of the British Empire ) title from Queen Elizabeth, United Kingdom for his services in interfaith relations and civilization. [3] Then on August 28, 2014 he received the MIPI Award ' in the category of Government Observer from the Indonesian Government Society (MIPI ). Subsequently, on August 4, 2014, he was awarded the ' Commendations' from the Japanese Ministry of Foreign Affairs for his services in strengthening mutual understanding between Japan and Indonesia; and 18 September 2014 he was selected as one of the three recipients of Japan's 2014 Fukuoka Prize prestigious award for his services and significant contribution in increasing the understanding of the international community towards Asian culture; he also on June 25, 2015 received the 'Dedicated Scholar 2015' award by Kompas Daily ; on August 20, 2015 delivered the ' Sarwono Memorial Lecture ' in commemoration of the 48th anniversary of LIPI, and on August 21, 2015 received the 2015 Achmad Bakrie Award in the field of Social Thinking. Azra was also among the 10 best Indonesian scientists from Webometrics data in February 2015. The October 2015 data of Azra's Webometrics was among the Top 20 Indonesian Scientists and ranked 7th out of 1000 people in the world. In 2017 Azra won two awards from the Japanese government namely The Order of Rising Sun: Gold and Silver Star and LIPI, namely Sarwono Parwirohardjo Memorial Lecture (SML) .

Azra's works are very much quoted by various groups, both at home and abroad. This makes Azra as one of the lecturers at the Islamic Religious College received 9072 citations with an h-index of 44. [4] Aside from Azra being referred to by various groups, he not only has expertise in one field, but also in various disciplines, so that he deserves to be called a complete Indonesian Muslim intellectual figure. Here are delivered some of his expertise, making him as an Indonesian Muslim intellectual leaders of the world :

\subsection{Historian}

Azra obtained a Ph.D in history ( Doc tor of Philosophy, Columbia University , 1992 ), and two masters, namely from the Middle East Language and Culture Department (S2 Languange and Culture of Eastern Department, Columbia University , 1988), and from the Department of History (S2 History Department, Columbia University , 1989). Azra also obtained an M. Phil ( Master of Philosophy, Columbia University , 1990). Azra is a network of scholars in the 17th and 18th centuries. The actual title is The Transmission of Islamic Reformism to Indonesia: The Network of Middle Eastern and Malay-Indonesian "Ulama" in Seventeenth and Eighteenth Centuries . [1] Azra's expertise in the field of history brought him as a prominent historian in Indonesia, so he became one of the figures who were sought after by the media to be asked for his opinion on the development of Islam in the world.

History, as sound of a phrase, recovered, remembered, and invented ..., 'wrote Azra. History is often lost because it is undocumented, and every time it is rediscovered, although this form of rediscovery is never the same as an 'original' event - which may still be traced. Thus, Azra's view of history is a discursive view; he understands history as a discourse created by a network of power relations. [5]

This does not necessarily make history less important to be taken seriously. Besides, there are no things in this world that can exist out of control, from historical stories handed down from generation to generation, humans can continue to look in the mirror and learn. [5] Whenever reading or enjoying Azra's thoughts in the form of books, writings in the mass media and interviews, the reader feels taken to the side of the world which is quite exciting: the world 
of doctrine (Islam) and the world of history. Azra is indeed very good at concocting and knitting the two worlds, so that his thoughts seem deep and strong. [6] His ability to write history - specifically the development of Islam - with solid and valid data has been tested. [1]

In some of his thoughts, Azra is quite fluent in speaking about theology (' aq î dah ), Islamic mysticism ( tasawwuf), and law ( fiqh, syarî‘ah ). That is what is meant by the world of Islamic doctrine, which is often found in Azra's thinking. Also, Azra quite often associates the study of his thoughts with the world of history, especially the history of the scholars who have indeed become his study choices. [6]

Islamic doctrine becomes the main grip for every Muslim . Without understanding and realizing Islamic doctrine, Muslim individuals will experience a deadlock in living life. Therefore, it is very appropriate for Azra to use Islamic doctrine as a reference for his thought analysis. With that reference base, Azra wants to open the mind and heart of the reader. So, the reader is increasingly convinced of religion and can increase faith and devotion to Allah. Also Azra's choice of historical studies. History, as mentioned in the Qur'an, is 'ibrah , and humans are required to pay attention to it. History can be a mirror and humans can learn from human history. That is, history can be used as a reference to build the future of Muslims. [6]

Thus, Azra actually has made Islamic doctrine and history as a reference guide to enrich his thoughts. The combination of the two world approaches in his writings further enriches and broadens insights the horizons of Islam, when reading and understanding them. [6]

\subsection{Cultural practitioner}

Azra as a cultural practitioner, is not in doubt. Azra talked a lot and wrote about culture, even Azra was one of the figures who received national and international awards because of her involvement in culture.

Azra said that religion, including Islam, contained symbols of the socio-cultural system that provided a conception of reality and a design to make it happen. However, the symbols relating to this reality do not always have to be the same as the reality that is manifested in real life in society. In this sense, religion is understood as a "cultural system". [6]

On Tuesday, the end of September 2010 was a historic and happy day for Azra, he was awarded the title of Commander of the Order of the British Empire (CBE) from the United Kingdom, Queen Elizabeth, in Jakarta. The title was handed over by the British Ambassador to Indonesia, Martin Hatfull. [7]

In 2014, Azra was also awarded the Fukuoka Prize . The Fukuoka Prize is an award bestowed by Fukuoka City and The Yokatopia Foundation, Japan in recognition of the highest achievements of individuals or organizations in preserving Asian culture. The 2014 Fukuoka Prize was awarded to three recipients ( laurates ); Professor Ezra F. Vogel, Professor of Sociology Emeritus Harvard University who was awarded the grand prize ; Azyumardi Azra, Proffesor of History UIN Syarif Hidayatullah Jakarta as recipient of academic prize ; and Danny Young, Cultural Practitioner ( Hong Kong) for the arts and culture prize . They were chosen by the Jury among 239 nominees from 29 countries. [8]

Professor Azyumardi Azra, the quote of the Jury was that he was a prominent historian, progressive educator and intellectual Muslim who was determined to fight for a moderate understanding of Islam. He made a major contribution to the creation of a multicultural and harmonious civil society in Indonesia. In its practical activities - rooted in its deep understanding of Islamic culture, it contributes greatly to the cross-cultural understanding of the international community. [8] 
In 2015 Azra was one of six figures who won the XIII Achmad Bakri Award (PAB) . The six figures from various backgrounds were chosen and appointed as the recipients of the XIII PAB by a panel of judges working independently. Azra was awarded an award as a social thought scientist who has contributed to the treasures of Islamic knowledge. Especially about the Islamic world as a network of ideas that flows from one region to another with dynamic and inspiring mutual inspiration. [9]

\subsection{Political observer}

According to Azra, politics is a matter of worldly that can make people drunk ( $\mathrm{h} u b$ Dunya ). Therefore, in order to avoid a split, the schollars should not too oriented on politics and power. Moreover, politics is often manipulative. Azra deeply regrets if the ulama are swept up in the flow of politics and power. [1]

In one of his interview sessions with Kompas daily, Azra gave an overview of the political world from an Islamic perspective. According to him, there are two big views in the Islamic world about this. The first group are those who believe that politics is an integral part of religion. Din (religion) is inseparable from siyasah (politics) because Islam covers all aspects of life. People who belong to this first group tend to involve themselves in the world of praxis politics, and try desperately to establish an Islamic state. The second category is those who believe siyasah should be separated at all from the din, although that one is part of the other. This is because the din is divine, while siyasa is very profane. [5]

As a former student activist, indeed he was accustomed to thinking critically about power. This means being critical of the prevailing political systems and practices. In addition, Azra claimed that he had never had any aspirations to earn a living in the political path. He prefers fortune to come from the path he likes, such as teaching, writing, and discourse. The fact that he is not aiming for a position made him even more comfortable on campus. [5]

The only contact between Azra and the realm of practical politics was only when he was appointed as a member of the Indonesian People's Consultative Assembly (MPR) from the Group's representatives until the end of the Soeharto government in 1997-1998; it also became an interim member to replace Professor Quraish Shihab. Group Representatives are representatives of community members from certain 'groups' to sit in the MPR. Groups that exist in society, such as teachers, farmers, religious leaders, and others. [5]

After the reformation, Azra saw many political practices that were not compatible with democracy or political ethics. This made him even more convinced that he could be more useful outside the 'arena,' and not inside. He is also active in speaking in many forums in many circles, serving interviews with various media, writing newspaper articles, conference papers, and books concerning politics, especially democracy. [5]

The period 1999-2006 was a fertile period in Azra's authorship. During this time, he produced many writings, papers, columns and articles. Some of it was collected in book form, so that during this time, he launched his books twice, each with six copies. In addition, various lengthy, more academic articles relating to democracy, civil society, good governance , and Islam-politics in English are published as chapters in books published internationally.[5]

His active writing activity about issues that not directly related to Islam, make Azra criticized in a forum by a colleague teachers and officials in the IAIN. Once upon a time, in 2000, the Ministry of Religion held a meeting of the Chancellor and Vice Chancellor for Student Affairs in IAIN throughout Indonesia in Jakarta. Azra came with Nasaruddin Umar who at that time served as Assistant Rector III IAIN Syarif Hidayatullah. In the middle of the event, IAIN Sunan Kalijaga Yokyakarta's Vice Rector III, Ismail Lubis (late, died in 2005) 
protested against the Chancellor of the Jakarta IAIN which at that time was better known as a political observer than an academic. [5]

Azra is not angry at this criticism. He only said, it was not him who gave the predicate and not his own will to talk a lot about political issues. The issues that revolved around those days were generally about politics and the media, apparently, believing him to be a resource that was worth quoting. Anyone cannot propose himself to be a media resource; is the media and the public themselves who seek and find sources that are in accordance with their wishes. " This is public recognition that cannot be forced," he said. [5]

Azra did not feel negligent in carrying out his responsibilities as an academic. $\mathrm{He}$ continues to carry out his duty of carrying and developing IAIN Jakarta to become UIN. Not only academically, but also physically by rebuilding campus. [5] Azra considers the achievement of UIN beyond what had been imagined ( beyond imagination ). UIN Jakarta include a Top State Universities (PTN) in the middle chessboard of State Universities (PTN) Indonesia. He is the only ex-institute (IAIN and Teachers' Training College) which has a Faculty of Medicine and Health Sciences.[10]

\subsection{Education Practitioners}

The idea of modernizing Islamic education in Islamic universities is not only a discourse, but must become a reality and practiced by Azra. The practice has been reflected in his reform efforts at UIN Syarif Hidayatullah Jakarta. The idea of Islamic education reforms proposed by Azra also includes renewal of madrasah education, pesantren and surau.[11] From various opinions, Azra formulated, that education is a process in which a nation prepares its young generation to run lives and to fulfill life's goals effectively and efficiently. He emphasized that education is more than just teaching. Education is a process in which a nation or country fosters and develops self-awareness among individuals. [12]

Education really is a physical, mental, and moral exercise for individuals, so that they become civilized human beings. With education, these individuals are expected to be able to fulfill their duties as human beings - created by Allah SWT as a perfect being and chosen as His Khalifah on earth, and to become a meaningful and beneficial citizen of a country. In other words, if the word education is coupled with the word Islam, as emphasized by Azra, it means a process of forming individuals which is based on Islamic teachings revealed by Allah to the Prophet Muhammad. With this kind of (Islamic) education process, the individual is formed, so that he can reach a high degree, and be able to fulfill the functions and duties of his caliph on earth, and succeed in realizing happiness in the world and the hereafter. [12]

As an education observer, Azra is very productive in conveying her thoughts, both in various print and electronic media, as well as in seminars, both nationally and internationally. Azra has written three books relating to the world of education, namely Muslim Intellectual Essays and Islamic Education (Tangerang: Logos, 1998);[12] Islamic education; Tradition and Modernization Towards the Third Millennium (Jakarta: Logos, 1999)[3], this book is refined to be: Islamic Education Tradition and Modernization in the Middle of the Challenges of the Third Millennium (Jakarta: Kencana, 2012); The National Education Paradigm for Reconstruction and Democratization (Jakarta: Kompas, 2002).[13]

The three books are a collection of essays, both in the form of articles that have been published in various media and also papers in various seminars. Its scope is broad, since Islamic universities, repositioning madrassas, IAIN vision, education and regional autonomy, people's universities, to the philosophy of education. [5] 


\section{Conclusion}

Azra is fulfilling the criteria as a global Indonesian Muslim intellectual figure, this can be seen from several things, first ; the results of his work, both in written form and work in the development of Islamic religious colleges, second ; awards he received from various countries and international institutions, third ; activity in several international organizations, and fourth ; is often invited as a guest speaker in various international event.

\section{References}

[1] A. Azra, Islam Substantif. Bandung: Mizan, 2000.

[2] I. .M, "Context of Scientific and Institutional Renewal in Islamic Higher Education (PTKI): A Study on Azyumardi Azra's Thought 1998-2015,” MADANIA J. Kaji. Keislam., 2018.

[3] Azyumardi Azra, Pendidikan Islam: Tradisi dan Modernisasi di Tengah Tantangan Milenium III. Jakarta: Kencana, 2012.

[4] Scholar, "Biografi Azyumardi azra."

[5] A. Dwifatma, Cerita Azra: Biografi Cendikiawan Muslim Azyumardi Azra. Jakarta: Erlangga, 2002.

[6] A. Azra, Konteks Berteologi di Indonesia: Pengalaman Indonesia. Jakarta: Paramadina, 1999.

[7] K. Inggris, R. Elizabeth, P. M. Inggris, T. Blair, and I. Susilo, "Gelar CBE Setelah Empat Tahun UIN Jakarta Ikut Pameran," pp. 93-103, 2010.

[8] M. Sudiaman, "Fukuoka Prize," Republika.co.id, Sep-2014.

[9] D. Priatmojo, "Mantan Rektot UIN Jakarta Raih Penghargaan Achmad Bakrie," viva.co.id, 2014.

[10] D. AMIN, ROHAINI, Ulama Melayu Nusantara Peranan dalam Institusi Islam, 1st ed. SELANGOR MALAYSIA: JAIS-KUIS SELANGOR, 2018.

[11] I. .M, "Gagasan dan Pemikiran Serta Praksis Pendidikan Islam di Indonesia (Studi Pemikiran dan Praksis Pendidikan Islam Menurut Azyumardi Azra)," Edukative, vol. 2, no. 2, 2017.

[12] A. Azra, Esai-esai Intelektual Muslim dan Pendidikan Islam. Jakarta: Logos, 1999.

[13] A. Azra, Paradigma Pendidikan Nasional Rekosntruksi dan Demokratisasi. Jakarrta: Kompas, 2002. 